\title{
Inclusion and Equality in Contemporary Urban Housing: The Case of Riga
}

\author{
By Santa Freimane ${ }^{1}$
}

\begin{abstract}
The residential environment plays a significant role in a city's sustainable development. It should also contribute to inclusion and equality in the socio-cultural dimension. Each year in Riga, capital city of Latvia, new residential developments appear. Little is known about how these developments contribute to the overall goal of sustainability, especially in terms of inclusion and equality. This research focuses on several issues related to inclusion and equality in Riga's 21st century residential developments, with the aim of gaining a deeper understanding of current trends as well as possible evolution. Theoretical methods include analysis of urban and architectural plans, legislation, strategies, development programmes and other documented sources. Empirical methods include field studies and the analysis of statistical and sociological data. The major findings indicate that the first steps towards sustainable urbanism have been taken. However, isolation, creation of gated communities, urban fragmentation and segregation have led to a mediocre situation in terms of inclusion and equality. The current situation should be improved in order to increase the quality of life of all citizens and to contribute to the goal of sustainable development.
\end{abstract}

Keywords: residential environment; inclusion and equality; sustainable urbanism; housing developments

\section{Introduction}

Riga, the capital city of Latvia and part of the European Union, is working towards the goal of sustainable development. Riga faces numerous challenges such as population shrinkage, urban sprawl, lack of investments, and other threats. In this context, quality housing is one of the prerequisites to ensure quality living conditions for citizens as well as to contribute to sustainable urban development. In the period of 20002019, approximately 24,000 new apartments were built in Riga (Centrālās statistikas pārvalde, 2010b; Centrālās statistikas pārvalde, 2020a). Although previous researchers have described the general state of Riga's residential environment, few have addressed the question of inclusion and equality, especially of newly built residential developments. To evaluate how these new developments contribute to social sustainability, this paper examines several issues regarding inclusion and equality.

The primary objects of this research are housing developments built between 2000 and 2019. For this research, 50 residential complexes were selected. Selection was based on the following criteria: the projects consist of at least two buildings as one architectural ensemble, with at least 80 apartments and with at least the first construction phase completed. In some cases, a smaller range of case studies were selected and it is noted separately. Theoretical as well as empirical methods were used in this research. Field studies on selected cases were used to understand the present situation and issues related 
to inclusion and equality. To evaluate quality, a checklist adapted from prior literature review was developed and implemented. An analysis on sustainable strategy as well as statistical and sociological data was used to explore Riga's context and its influence.

The collected data was analysed to gain deeper knowledge regarding inclusion and equality. Our hypothesis was that Riga's newly built residential developments help to ensure inclusion and equality in housing, thus contributing to the overall sustainability of the city. The following research questions regarding Riga's newly built residential developments were defined: What is the importance of equality and inclusion in terms of housing? What are the challenges of housing in Riga, and how does Riga's context affect inclusion and equality in newly built residential developments? What is the level of inclusion and equality in terms of housing availability, spatial situation and other factors?

\section{Importance of Equality and Inclusion in the Residential Environment}

Inequality is a multidimensional problem and can be measured in many ways. Broadly speaking, it can be broken into two primary concepts: inequality of results, meaning income and wealth, and inequality of opportunities. It is broadly believed that some degree or types of inequality can promote investment in human capital and stimulate innovation, which is important for economic development and growth, but this relies on the possibility for an individual's hard work to result in higher income. However, if inequality becomes too high, it can adversely affect economic growth (European Commission, n.d.).

The 2017 report of the European Federation of Public, Cooperative and Social Housing on the state of housing in the European Union concluded that housing inequalities are directly linked to income inequality, and they are mutually reinforcing. Rising real estate prices are widening the gap between rich and poor (Pittini, Koessl, Dijol, Lakatos, \& Ghekiere, 2017). A study on housing inequality commissioned by the Council of Europe Development Bank also indicates that housing inequality is both a symptom and a cause of income inequality. Housing inequalities are related to indicators such as income inequality, housing quality and location as a manifestation of spatial segregation, which in turn limits the availability of other services (Omic \& Halb, 2017). Moreover, inequality undermines social justice. In situations where economic resources are distributed too unequally, social cohesion and the general sense of belonging can be weakened, thus creating a greater risk of insecurity, homelessness or social exclusion. Furthermore, unequal opportunity leads to greater income inequality as the skills and earning potential of the next generation become increasingly diverse due to different starting positions. The provision of quality social services is an essential tool for combatting growing inequalities of opportunity. Significant measures to stop the transmission of disadvantage from one generation to the next include the provision of social housing (European Commission, n.d.).

Fair and equal housing requires adequacy in the following categories: availability of housing stock; condition of housing, such as quality of walls; housing amenities, such as water supply and electricity; housing affordability, taking into account all expenses; spatial integration of housing and availability of other basic services such as health care, education and public transport; environmental factors of the location, such as air quality, 
noise level and level of daylight; area and size of the dwelling, area of the living space per person and number of rooms per person in the dwelling; social factors of housing availability - for example, fair treatment of homeowners and neighbours towards certain social groups (Office of the high commissioner for human rights, 1991).

Previous studies have emphasised the negative effects of the long-term geographical concentration of households from one particular ethnic or socioeconomic group (van der Laan Bouma-Doff, 2007; Walks \& Bourne, 2006). In order to provide social inclusion, several countries have implemented various mixing strategies. For example, Sweden's policy aims to change not only the social and physical structure of disadvantaged neighbourhoods, but also to create cities that are socially mixed in their entirety, thus stimulating inclusion of different social groups (Holmqvist \& Bergsten, 2009). Furthermore, the United Nations encourages creation of integrated and mixed communities to ensure adequate housing and to avoid gentrification and segregation [8]. The most commonly cited benefits of mixing strategies are the potential to achieve a wider cross section of the population in a given area, encouragement of variety of social interactions, assurance of equality and avoidance of place-based stigmas (Monk, Clarke \& Tang, 2011; Randolph, Wood, Holloway \& Buck, 2004). Although diverse mixing policies have been implemented across Europe, research indicates that these strategies fail to reduce the segregation of minority ethnic groups. Moreover, mixing policies can also negatively affect the society, such as by breaking up some communities and constraining the choice of housing (Bolt, Phillips \& Kempen, 2010).

\section{The Context of Riga and Its Housing Challenges}

In the period of 2000-2019, the population of Riga decreased by $17.5 \%$, but the population of its metro area increased by 3.5\% (Centrālās statistikas pārvalde, 2020b). The Organisation for Economic Co-operation and Development (OECD) pointed out that Riga's urban sprawl is driven by low-density development that can negatively impact not only the economy, but also the quality of life of citizens. Such residential segregation may result in unequal access to quality education. Although the segregation level in Riga is lower in comparison to other European capital cities, it is tending to increase. Moreover, municipalities are individually adjusting their spatial planning policies to maximise revenues by attracting high income households. Municipalities may lack social housing that may attract lower income households (Glocker \& Fuentes Hutfilter, 2018). More and more people are choosing to live in agglomerations because of lower real estate prices and subjectively better living conditions. However, $75 \%$ of the residents of these agglomerations commute daily to Riga (Felcis, N̦ikišins \& Zača, 2014). Although it is expected that Riga's population will continue to decrease and in 2030 will be around 540,000 (Eglīte, Ivbulis, \& Gņedovska, 2012), Riga’s Sustainable Development Strategy for 2030 states that Riga's population must increase to 700,000 in order to ensure further urban development (Riga City Council City Development Department, 2014). In this context, ensuring a quality living environment and accessible housing is one of the target goals.

Latvia and its capital city of Riga face the following problems regarding housing: lack of policy planning documents; low income level and income inequality, which decreases 
household ability to cover housing expenses; insufficient amount of support; long queues for municipal and social housing (up to 12 years); mismatch between the housing stock and the population; ageing of the housing stock and low levels of housing renovation and construction; disorder in the construction and rental market of rental housing; complicated private-public relations in the field of housing; lack of a unified approach in the provision of housing support in local governments and insufficient access to temporary housing for specific target groups (Baltic Institute of Social Sciences, 2019). The construction of new as well as renovation of existing housing stock, development of current legislation, reduction of tax and administrative barriers in the housing market, including the rental market, to prevent stagnation are expected to reduce the severity of the current housing problems (Baltic Institute of Social Sciences, 2019; Riga City Council City Development Department, 2014; Parādnieks, 2018).

However, several risk groups face the following issues regarding housing equality and inclusion. Families with children often do not correspond to the status of poor or lowincome, but their income level makes it difficult to obtain housing in the private sector. Seniors over the age of 65 who live independently struggle with the financial burden related to housing expenses. People with disabilities face limited support for finding housing adapted to their needs, which requires significant capital investment. Young people after out-of-home care often have insufficiently developed social skills necessary for independent living. The housing benefit granted by the municipality is insufficient, and there lacks a common approach to determining this benefit. Victims of violence face challenges with housing security. Refugees face difficulties depending on their legal residence status and the residence permit they hold, which determine the housing assistance available to them. This target group faces difficulties regarding their visual difference, language barrier and low solvency. Roma people face similar challenges to other impoverished groups, but these are compounded by relatively low housing management skills and a lack of understanding of the need to cover housing costs, making it difficult to obtain housing. Persons released from prison, who have lost social ties with a family and friends, often lack support systems, and thus lack temporary housing. As a result, the risk of relapse is high while waiting for housing. Homeless people, in many cases not granted the status of a needy person, have limited access to social assistance from the municipality. They are characterised as having low social functioning skills for living independently and low levels of motivation and participation in solving their social and financial problems, which threatens their chances of obtaining proper housing (Baltic Institute of Social Sciences, 2019).

\section{Inclusion and Equality Assessment of Riga's Newly Built Residential Developments}

\subsection{Availability of housing stock}

To ensure that people's housing needs are met, a sufficient stock of housing is crucial. During the last two decades, the real estate market of Riga has experienced significant changes, which have been influenced by political decisions as well as economics and other factors. During a period of economic growth, 3,000-4,000 new apartments were built per year (Centrālās statistikas pārvalde, 2010b; Centrālās statistikas 
pārvalde, 2020a). New construction sharply decreased in 2009 due to the economic downturn and has in recent years slightly recovered, reaching almost 1,500 new apartments per year (Fig. 1) (Centrālās statistikas pārvalde, 2020a).

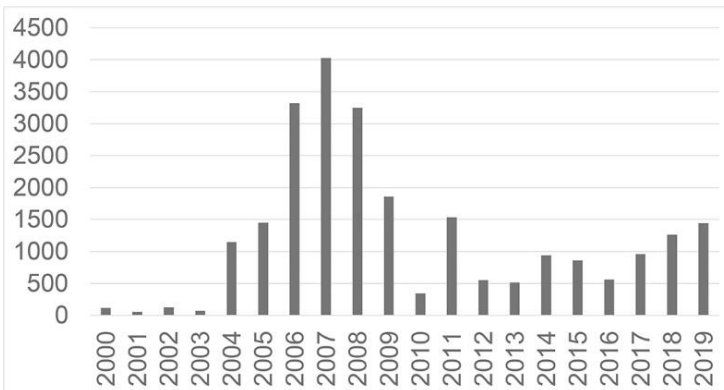

Figure 1: Constructed Apartments in Riga in the period of 2000-2018.

Data source: (Centrālās statistikas pārvalde, 2010b; Centrālās statistikeas pārvalde, 2020a)

The period between 2000 and 2019 saw the construction of 24,390 apartments, totalling $2,842,000 \mathrm{~m}^{2}$, which represents $14.4 \%$ of total housing stock (Centrālās statistikas pārvalde, 2010a; Centrālās statistikas pārvalde, 2010b; Centrāāās statistikas pārvalde, 2020a). This new housing stock includes the 50 largest new residential developments, with at least two buildings in one architectural ensemble, with a minimum of 80 apartments and completed at least 1st construction phase. Among these 50 largest apartment complexes, six are social housing projects. However, according to the statistics on April 1st, 2019, 3,385 households were registered to receive assistance in resolving their housing issues (Rīgas domes informativvais portāls, 2019), indicating the shortage of social housing.

\subsection{Spatial distribution of housing}

New residential developments have been built all around the city, increasing the opportunity for residents to obtain housing in their preferred neighbourhood (Fig. 2).

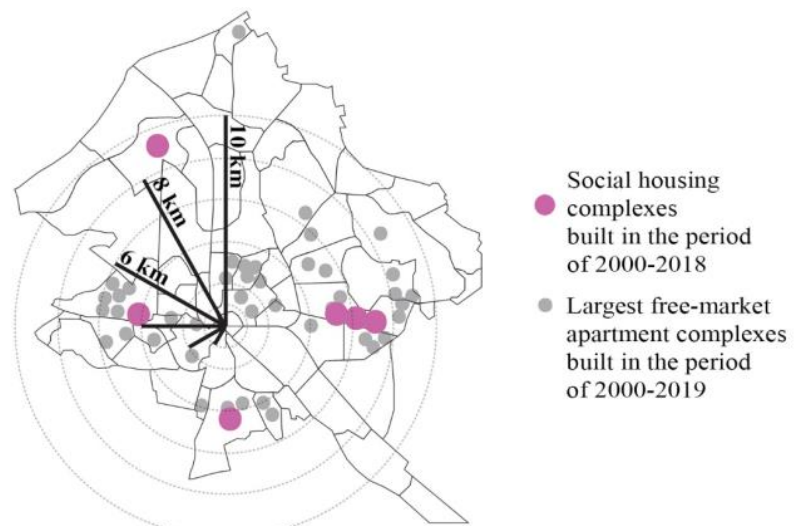

Figure 2: Spatial distribution of Riga's largest 21st century apartment complexes built between 2000 and 2009. Data source: Rìgas Pilsètbüvnieks, 2014; "Jaunie projekti - Meklèt - City24," n.d. 
New free-market residential projects have been developed separately from social housing projects. Although new social housing developments, which are located in several residential neighbourhoods and in the city's periphery, are still within the limits of the city and in locations with access to other services, such as public transport, spatial segregation is still occurring due to separated development. In the current situation, each residential development is focused on one socioeconomic group and there are no mixing strategies, such as those using "salt and pepper" principles, where social housing is distributed among other housing types. Considering that some social housing projects consist of more than 800 housing units, the threat of spatial segregation in particular neighbourhoods is significant.

\subsection{Housing affordability}

In Q2 of 2019, the housing affordability index (HAI) reached 182.1 points. However, for new projects and renovated apartments, the HAI was only 130.3 points (Swedbank Research, 2019), which indicates the gap between the affordability of newly and previously constructed housing. Housing affordability by income quintile groups (Table 1) shows that if a monthly mortgage payment of 366 euros does not exceed 30\% of household income, only the upper 4th and 5th quintile group can afford this payment. In 2018, these quintile groups covered a total of approximately $52 \%$ of Riga's residents (Centrālās statistikas pārvalde, 2020c). The 1 st and part of the $2^{\text {nd }}$ quintile group are most likely to be for social apartment assignment or housing benefits. However, the 3rd quintile group, which may not qualify for help with housing, most likely cannot afford housing in the newly built residential developments. Although there is a chance that people in the 3rd quintile group can afford an apartment in a residential building from a previous construction period, the fact that newly built residential complexes are available only for certain socioeconomic groups reinforces inequality and may weaken social cohesion.

Table 1. Ability to cover mortgage loan by quintile groups

\begin{tabular}{|l|c|c|c|c|c|}
\hline Quintile group & 1 & 2 & 3 & 4 & 5 \\
\hline Percentage of households in Riga, 2018 & 13.0 & 15.7 & 18.9 & 22.7 & 29.7 \\
\hline Disposable income of households, 2018 & 412.18 & 693.59 & 1100.79 & 1544.80 & 2395.82 \\
\hline $\begin{array}{l}30 \% \text { of monthly income that can be accumulated for } \\
\text { the first instalment and allocated for the monthly } \\
\text { loan payment }\end{array}$ & 123.65 & 208.08 & 330.24 & 463.44 & 718.75 \\
\hline $\begin{array}{l}\text { Possibility of paying a monthly mortgage payment } \\
\text { of 366 euros for a 60 } \mathrm{m}^{2} \text { apartment with a price } \\
1,600 \text { euros/ } \mathrm{m}^{2} \text {; on a 25-year loan with an annual } \\
\text { interest rate of 2.5\% and a 15\% down payment } \\
\text { (using SEB Bank calculator), Euro }\end{array}$ & $-242,35$ & $-157,92$ & $-35,76$ & 97,44 & 352,75 \\
\hline
\end{tabular}

Data source: Centräläs statistikas pärvalde, 2020c; Centräläs statistikas pärvalde, 2019; "Mäjokẹla kredìta kalkulators | SEB banka," n.d.

\subsection{Support programmes}

There are several municipal social assistance programmes regarding housing 
issues. The housing benefit is intended to cover the rent or management of a dwelling and the charges for services connected with the use of the dwelling. Each municipality determines the amount of the housing benefit, the procedure for payment and binding regulations (Latvijas Saeima, 2001). The other assistance available is social apartment, which can be obtained if the household falls into one of 10 categories, such as separately living pensioners with low income. The rent in social housing apartments is 0.06 euro/1 $\mathrm{m}^{2}$ and the municipality also covers a portion of the utility payments $-50 \%$ for water and sewage and 25\% for heating expenses (Rīgas domes informatīvais portāls, 2019). However, long queues of up to 12 years are common for municipal housing and social housing (Baltic Institute of Social Sciences, 2019). This is a serious threat to the goal of social sustainability and insurance of quality living conditions for all groups of society.

If a family with at least one child in certain age groups or a young professional has a steady income but does not have sufficient savings for the first down payment, it is possible to apply to a housing loan guarantee programme called ALTUM. The aim of this programme is to provide state aid for purchase or construction of housing, thus decreasing the amount of the first down payment required to get a loan (Attīstibas finanšu institūcija Altum, n.d.). As stated by Riga's City Council Housing and Environment Department, it is necessary to increase housing affordability to increase return migration to Riga, to help to stabilise the job market and to provide conditions for urban and economic development. This can be achieved by expanding the housing support programme for families, including the regulation of new tenancy ratios as well as providing public-sector rented housing (Parādnieks, 2018).

\subsection{Tenure types}

Since social and free-market housing projects have been developed separately, tenure types are also divided by project. Moreover, free-market housing projects are developed to sell apartments, and none have a primary focus on renting. Sociological survey data shows that $65 \%$ of respondents were homeowners, while $35 \%$ were renters, the majority of whom were living in social housing developments. Furthermore, statistics on the overall tenure distribution in Latvia shows that in 2015, 82.8\% of total housing stock was owned by homeowners, while 17.2\% were occupied by renters (Centrālās statistikas pārvalde, 2016). In some cases, such as the project "Dammes liepas", units are available for rent with buying rights ("Dammes Liepas," n.d.). Most often, however, the opportunity to rent depends on the availability of private landlords. In the beginning of 2020, according to data about Riga's newly built apartments on which construction had been completed, there were approximately 10 times the number of purchase offers than rent offers (“Jaunie projekti - Meklēt - City24," n.d.). In the current situation, opportunities for rental versus purchase are unequal.

In addition, tenure type relates to social factors of housing availability, which can mean discriminatory treatment of homeowners and neighbours towards certain social groups. Several groups of the population can be at risk of social exclusion such as former prisoners, Roma people, and families with children. Members of these groups face situations in which private homeowners refuse to rent them their property. At the same time, it should be considered that in the private housing market, homeowners are free to rent or sell their property for whatever reason and are not obligated to do so. In the case 
of municipality-administered housing, this factor should not have an impact, although this cannot be completely ruled out (Baltic Institute of Social Sciences, 2019).

\subsection{Design aspects}

By default, the design of new housing developments must be of adequate quality, due to current legislation, which requires quality construction and provision of housing amenities such as water supply, sewage, etc. However, as social and free-market housing projects are developed separately, it is important to evaluate the differences in terms of design. Examples of newly built social and budget class residential developments shows that new housing projects can be quite similar in their visual identity (Table 3), and this does not necessarily indicate a difference in tenure type. However, in high-end projects, differences in materials used can be visually detected. Outdoor spaces also stand out in high-end housing developments, where more expensive materials and more unique design solutions are implemented. In terms of the housing units, the biggest difference is in size. In social housing projects, area is restricted to the adequate minimum, where one-room apartments should be around 35 $\mathrm{m}^{2}, 2$-room apartments at $40 \mathrm{~m}^{2}, 3$-room apartments at $55 \mathrm{~m}^{2}$ and 4-room apartments at $65 \mathrm{~m}^{2}$ (Rīgas Pilsētbūvnieks, 2014). In free-market housing, area mostly depends on people's preferences and purchasing ability. Budget housing tends to be functional and not exceed the appropriate area. By contrast, high-end housing provides ordinary housing units as well as large apartments and multi-level housing with integrated workspaces or penthouses.

Table 3. Design comparison of Riga's 21st century social housing and free-market residential developments

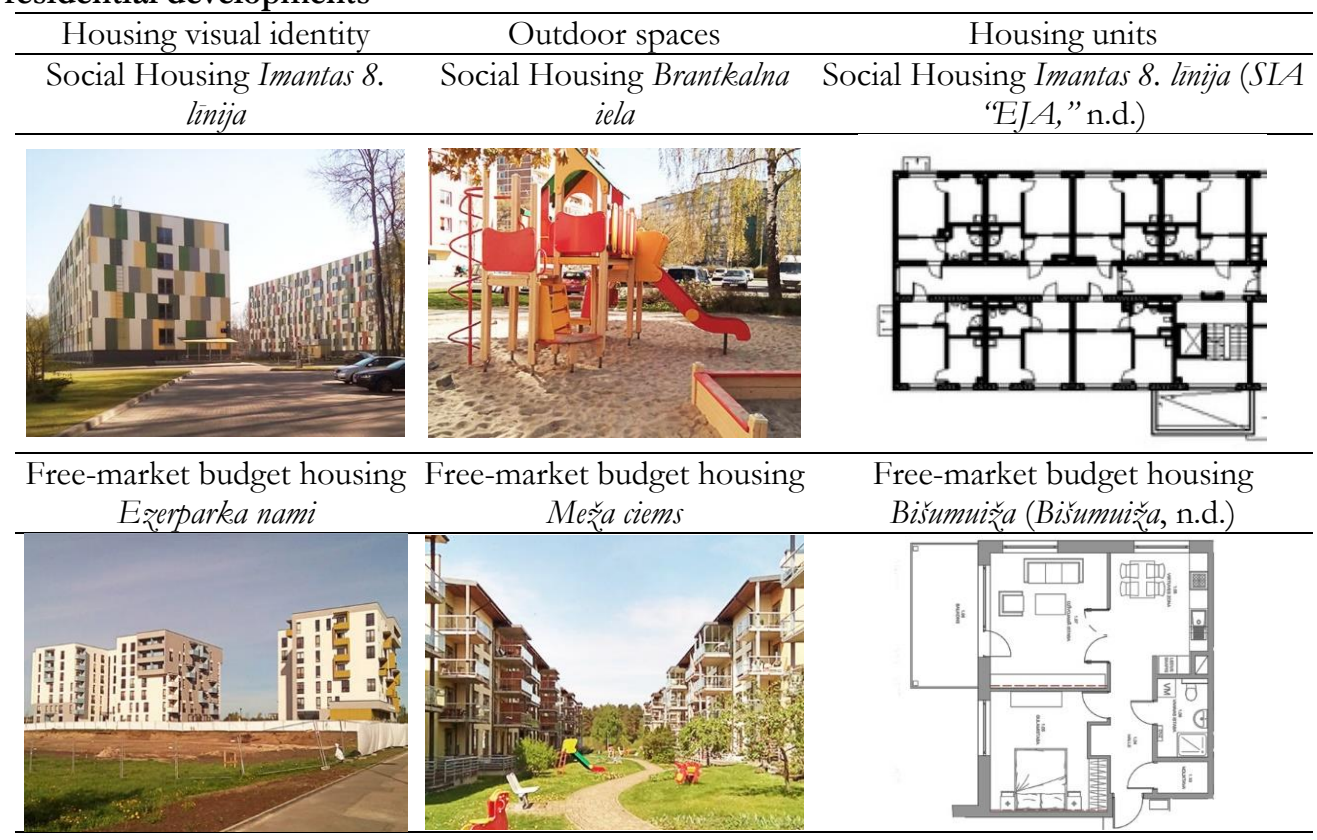




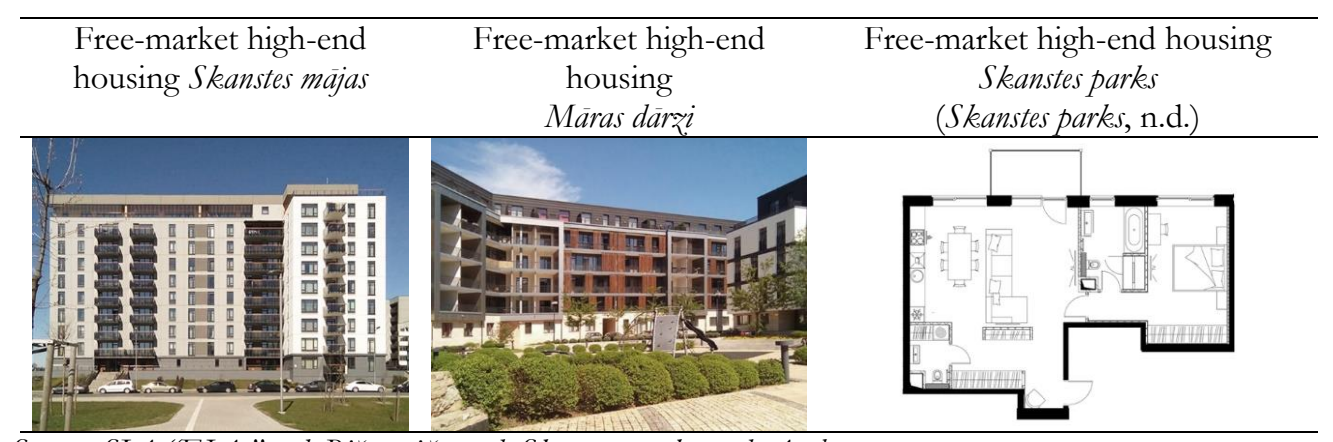

Source: SLA “EJA,” n.d; Bišumuiža, n.d; Skanstes parks, n.d; Author

\subsection{Gated communities}

Around 15\% of newly built residential developments are gated communities. Although such developments can create a strong sense of belonging and provide healthy community life within their borders, these developments tend to be isolated from other social groups. This approach may weaken social cohesion and fragment the spatial structure of the city. The majority of previous researchers define gated communities as a form of social segregation, demonstrated in theory and with empirical evidence (Balčaite \& Krupickaitė 2018).

Examples of Riga's newly built residential developments display different approaches to gating. In the project Solaris (Fig.4 a), the grounds are fenced, however during daytime, access by foot is not restricted. This kind of approach is open for social interaction with others while allowing residents to feel safe, because the gates can be locked when necessary. On the contrary, the grounds of project Kuldigas iela (Fig.4 b) are fully fenced, thus creating an isolated residential area. The project Meža ciems (Fig.4 c) has partially fenced areas. Each building has one side with open access, where parking and entrance zones are located, while the other side has fenced backyards with playgrounds for children and other activities.

Table 4. Examples of gating in Riga's 21st century housing projects

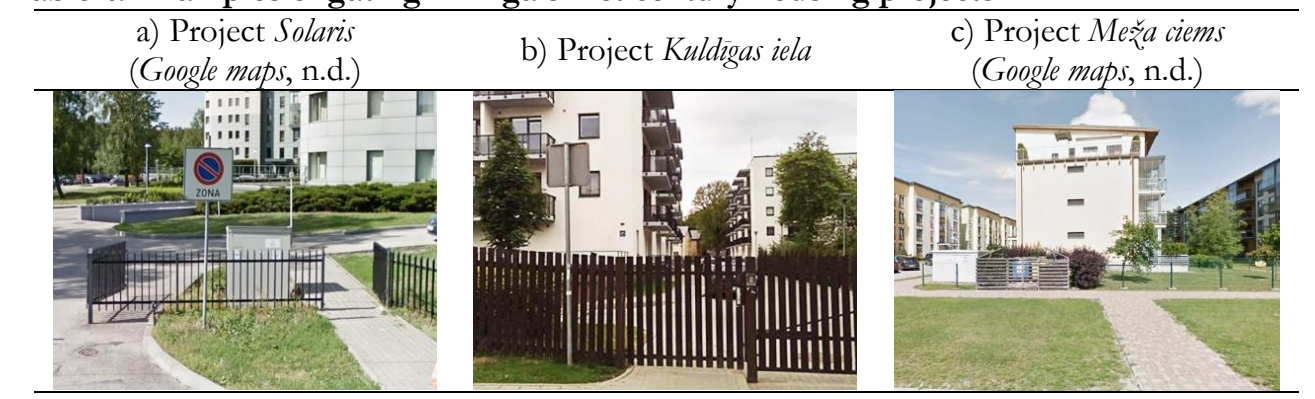

Source: Google maps, n.d.; Author.

\section{Conclusions}

Equality and inclusion are crucial aspects for achieving socially sustainable urban housing developments. Latvia and its capital city Riga faces major challenges regarding 
housing, including lack of housing policies and a poorly developed rental market. The main findings of this study indicate that although new housing stock has been built each year, thus increasing opportunities to obtain housing within the limits of the city, construction levels are low and there is still a shortage of social housing. Moreover, freemarket housing projects have been developed separately from social housing, thus increasing the risk of segregation and social isolation. Each newly built residential development tends to focus on a particular price range, which leads to socioeconomic homogeneity. This situation reduces the likelihood of social interactions between different socioeconomic groups and worsens inclusive urban development. Although there are several support programmes available for different societal groups, there are still several challenges, such as long waiting times for social housing. In terms of the rental market, chances of rent depends on private landlord availability mostly due to the fact that free-market housing is concentrated on apartment sales. The poor rental market puts households without purchasing power or who prefer to rent in a worse position than those who can and want to buy an apartment. Residential developments also differ in terms of design, especially by housing unit area. However, visual identity and outdoor spaces in social housing as well as in budget class housing developments are quite similar and here the difference is mostly visible in comparison to high-end housing projects where more expensive and unique solutions have been used. In several cases, a trend of gating can be observed. Although people have to have the right to choose how they want to live, and their preferences should be taken into account, it is important to have awareness that the gap between gated communities and other social structures can threaten the common good and weaken social cohesion. The overall situation can be described as mediocre and to increase social inclusion and equality in terms of housing, it is necessary to implement a wide range of tools and actions.

\section{References}

Attīstības finanšu institūcija Altum. (n.d.). Finanšu institūcija ALTUM | Valsts atbalsts. Retrieved February 3, 2020, from https://www.altum.lv/lv/

Balčaité, S., \& Krupickaite, D. (2018). Perspectives of gated communities' socio-spatial integration: the case of post-socialist Lithuania. Belgeo, (4). https://doi.org/10.4000/belgeo.23832

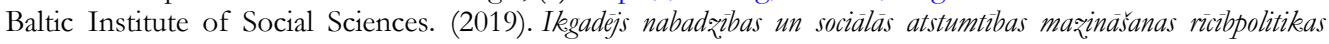
įvertējums. Retrieved from http://petijumi.mk.gov.lv/sites/default/files/title file $\triangle$ Nabadz soc atstumt mazin ricibpol izvertejums Zinojums.pdf

Bišmuiž̃a. (n.d.). Retrieved from https://www.bisumuiza.lv/lv/

Bolt, G., Phillips, D., \& Van Kempen, R. (2010). Housing Policy, (De)segregation and Social Mixing: An International Perspective. Housing Studies, 25(2), 129-135. https://doi.org/10.1080/02673030903564838

Centrālās statistikas pārvalde. (2010a). A_MAG030. Užbūvètās jaunās drivivojamās èkeas statistiskajos rẹ́ionos, republikas pilsètäs un rajonos (tūkest. $m^{2}$ kopējäs platïbas), 1990.-2009.g. [Dataset]. Retrieved from https://data.csb.gov.lv:443/sq/36018

Centrālās statistikas pārvalde. (2010b). A_MAG050. Uz̧būvèto džìokẹlu skaits statistiskajos reǵionos, republikas pilsètäs un rajonos, 1997.-2009.g. [Dataset]. Retrieved from https://data.csb.gov.lv:443/sq/35771

Centrālās statistikas pārvalde. (2016). EPM120. Mäjoḳ̂lu sadalïums pēe èkeas tipa un ïpašuma formas (\%) [Dataset]. Retrieved from https://data1.csb.gov.lv:443/sq/35998

Centrālās statistikas pārvalde. (2019). IIG090. Mäjsaimniecību rīībà esošie ienākumi kevintịlu grupās (euro, mēnesi) [Dataset]. Retrieved from https://data.csb.gov.lv:443/sq/35773 
Centrālās statistikas pārvalde. (2020a). BUG050. Ekspluatāijāā piennemto jauno dřìvokịlu skaits un platība statistiskajos reǵionos, republikeas pilsètäs un novados [Dataset]. Retrieved from https://data.csb.gov.lv:443/sq/36016

Centrālās statistikas pārvalde. (2020b). ISG020. Iedæ̃ivotäju skaits un tã ị̌mainas statistiskajos reǵgionos, republikas pilsètās, novadu pilsètās un novados [Dataset]. Retrieved from http://data1.csb.gov.lv/sq/36015

Centrālās statistikas pārvalde. (2020c). MVG070. Mäjsaimniecïbu sadalīums pèc kvintilu grupäm (\%) [Dataset]. Retrieved from https://data.csb.gov.lv:443/sq/35772

Dammes Liepas. (n.d.). Retrieved February 3, 2020, from http://www.dammesliepas.lv/rent/?lang=lv\#/irear-izpirkuma-tiesibam

Driviojamās èkeas ar sociäliem drivivokliem, veselïbas centru un Rïgas sociälä dienesta teritoriälo centru. (n.d.). Retrieved from https://buvlaukums.lv/lv/portfolio/portfolio/buvlaukumslvpublikacijas/architecture/46/

Eglìte, P., Ivbulis, B., \& Gñedovska, I. (2012). Demogräfiskās prognozes Rigà un Pierìgà. Retrieved from http://www.sus.lv/sites/default/files/media/faili/demografiskas prognozes riga un pierig a rd lza 2012.pdf

European Commission. (n.d.). Eiropas pusgada tematiskä faktu lapa. Nevienlìdž̨bas novèršana. Retrieved from https://ec.europa.eu/info/sites/info/files/file import/european-semester thematicfactsheet addressing-inequalities $\mathrm{lv}$.pdf

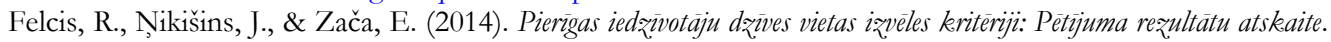
Retrieved

from http://www.sus.lv/sites/default/files/media/faili/lu_szf rd pierigas iedzivotaji atskaite par pet ijumu.pdf

Glocker, D., \& Fuentes Hutfilter, A. (2018, October 5). Making the most of Riga metropolitan area can boost wellbeing and economic growth in Latvia. Retrieved January 4, 2020, from https://oecdecoscope.blog/2018/10/05/making-the-most-of-riga-metropolitan-area-can-boostwellbeing-and-economic-growth-in-latvia/

Google maps. (n.d.). [Photograph]. Retrieved from https://www.google.com/maps

Holmqvist, E., \& Bergsten, Z. (2009). Swedish social mix policy: a general policy without an explicit ethnic focus. Journal of Housing and the Built Environment, 24(4), 477-490. https://doi.org/10.1007/s10901009-9162-0

Jaunie projekti - Meklēt - City24. (n.d.). Retrieved March 2, 2020, from https://www.city24.lv/lv/jaunie+projekti

Laan Bouma-Doff, W. van der. (2007). Confined Contact: Residential Segregation and Ethnic Bridges in the Netherlands. Urban Studies, 44(5-6), 997-1017. https://doi.org/10.1080/00420980701255965

Latvijas Saeima. (2001, December 6). Par palīdzību dzīvokḷa jautājumu risināšanā. Retrieved February 10, 2020, from https://likumi.lv/doc.php?id=56812

Mājokḷa kredīta kalkulators | SEB banka. (n.d.). Retrieved January 4, 2020, from https://www.seb.lv/kreditiun-lizings/majoklim/majokla-kredita-kalkulators

Monk, S., Clarke, A., Tang, C. Mixed Communities = Literature Review [online]. Cambridge Centre for Housing \& Planning Research [cited 02.10.2019]. https://www.cchpr.landecon.cam.ac.uk/Research/StartYear/2010/Mixed-Communities-Review/Report-to-Scottish-Government-Communities-AnalyticalServices/Mixed-Communities-Literature-Review

Office of the high commissioner for human rights. (1991, December 13). CESCR General Comment No. 4: The Right to Adequate Housing (Art. 11 (1) of the Covenant) . Retrieved January 5, 2020, from https://www.refworld.org/pdfid/47a7079a1.pdf

Omic, E., \& Halb, J. (2017). Housing inequality in Europe = Tackling inequalities in Europe: the role of social investment. Retrieved from https://coebank.org/media/documents/Part 3-Inequality-Housing.pdf

Parādnieks, I. (2018). Mäjoklı politika. Retrieved from https://www.pkc.gov.lv/sites/default/files/inlinefiles/1 pielikums I Paradnieks Majoklu politika 05042018 DLC.pdf

Pittini, A., Koessl, G., Dijol, J., Lakatos, E., \& Ghekiere, L. (2017). The State of Housing in the EU 2017. Retrieved from file:///C:/Users/SANTA/Downloads/FULL\%20Publication\%202017 web\%20(2).pdf

Randolph, B., Wood, M., Holloway, D, Buck, B. The benefits of tenure diversification ISBN: 1920758917 [online]. The Australian Housing and Urban Research Institute (AHURI) [cited 02.10.2019]. https://www.ahuri.edu.au/ data/assets/pdf file/0005/2030/AHURI Final Report No60 Be nefits of tenure diversification.pdf 
Riga City Council City Development Department. (2014). Sustainable Development Strategy of Riga until 2030 and Development Programme of Riga for 2014-2020 SUMMARY. Retrieved from https://www.rdpad.lv/wp-content/uploads/2014/11/ENG STRATEGIJA.pdf

Rīgas domes informatīvais portāls. (2019, April 23). Kā saņemt mājokli no pašvaldības? Retrieved January 4, 2020, from https://www.riga.lv/lv/news/ka-sanemt-majokli-no-pasvaldibas?16807

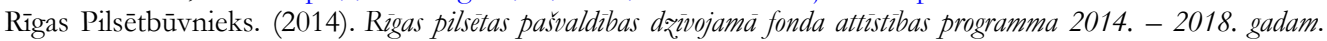
Retrieved from http://www.sus.lv/sites/default/files/media/faili/rigaspasvaldibasdzivojama fondaattistibasprogramma2014-2018.pdf

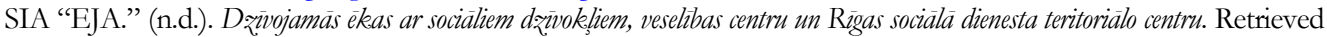
from https://buvlaukums.lv/lv/portfolio/portfolio/buvlaukumslvpublikacijas/architecture/46/

Skanstes parks. (n.d.). Retrieved from https://skanstesparks.lv/grostonas 12

Swedbank Research. (2019). Baltic Housing Affordability Index. Retrieved from https://www.swedbankresearch.com/latvian/baltijasmajoklu/2019 q2/hai q2 2019.pdf

United Nations. (2017). Habitat III Policy Papers: Policy Paper 10: Housing Policies. Retrieved from http://habitat3.org/wp-content/uploads/Habitat $\% 20 I I \% 20$ Policy $\% 20$ Paper $\% 2010 . p d f$

Walks, R. A., \& Bourne, L. S. (2006). Ghettos in Canada's cities? Racial segregation, ethnic enclaves and poverty concentration in Canadian urban areas. The Canadian Geographer / Le Géographe Canadien, 50(3), 273-297. https://doi.org/10.1111/j.1541-0064.2006.00142.x 